\title{
DUTIES AND LIABILITIES IN PRIVATE LAW
}

\author{
Peter Jaffey* \\ Brunel University
}

Private law is generally formulated in terms of right-duty relations, and accordingly, private-law claims are understood to arise from breaches of duty, or wrongs. Some claims are not easy to explain on this basis because the claim arises from an act that the defendant was justified in doing. The violation/infringement distinction seems to offer an explanation of such claims, but it is argued that the explanation is illusory. Claims of this sort are best understood as based not on a primary right-duty relation at all but on a "primary liability" or "right-liability" relation. A primary-liability claim is not a claim arising from the breach of a strict-liability duty. The recognition of primary-liability claims does not involve skepticism about duties or rules or legal relations and it is consistent with the analysis of private law in terms of corrective justice.

\section{INTRODUCTION}

Private law is generally understood in terms of rules that require or prohibit acts of one person for the benefit of another, and accordingly the law is generally expressed in terms of correlative right-duty legal relations between individuals. When a claim arises, it is because $\mathrm{D}$ breached a duty owed to C, or, in other words, D committed a wrong against C. But this understanding is too narrow: not all private-law claims have this pattern. The failure to appreciate this is behind much of the controversy surrounding the well-known case of Vincent v. Lake Erie, ${ }^{1}$ which is discussed in the first part of this article.

As a preliminary point, I should mention that I use the expression "claim" in what I take to be the usual legal sense, to mean a remedial right or right of action. This is not of course the same thing as a claim or claim-right in the Hohfeldian sense.

\footnotetext{
* I am grateful to my colleagues George Letsas and Emmanuel Voyiakis for their comments, and also to the anonymous reviewer. I am also grateful to Charles Rickett, head of the T.C. Beirne School of Law at the University of Queensland, where I spent two months of research leave in 2005 .
}

1. 109 Minn. 456, 124 N.W. 221 (1910). 


\section{CONFLICT BETWEEN RIGHTS OR DUTIES}

In Vincent v. Lake Erie, D moored his boat at C's dock during a storm. He did so, without permission from $\mathrm{C}$, in order to save his vessel from damage. Damage to the dock resulted, and $\mathrm{C}$ was held entitled to compensation. Normally a claim for compensation for harm caused by the unauthorized use of property is understood to be based on a wrong - a breach of the duty not to use the property. However, in Vincent, the court also declared that $\mathrm{D}$ had acted "prudently and advisedly" in the circumstances. This seems to imply that he did not commit a wrong and therefore that no claim should arise, and this is why the case has been so controversial.

Gardner argues that the question whether someone is justified in acting as he does is different from the question whether he commits a wrong against another person. ${ }^{2}$ He gives the example of someone who is late for work because he stopped to assist the victim of a mugging. According to Gardner, this person has acted justifiably but has also committed a wrong against his employer. Similarly, in Vincent, D both committed a wrong and acted justifiably. Gardner goes further and says that because D committed a wrong by using the dock, $\mathrm{C}$ would have been entitled to use reasonable force to stop him from doing so, although because $\mathrm{D}$ was acting justifiably he would also have been entitled to use reasonable force to secure his position on the dock. He recognizes that the possibility of a violent conflict between parties both justified in using force is "a potential problem for the law," but is satisfied that the problem can be overcome as and when it arises. ${ }^{3}$

On this view, Vincent is about an unresolved conflict between rights or duties. D had a duty not to use the dock but was also in the circumstances at liberty to use it. Or one might say that $\mathrm{D}$ had a duty to $\mathrm{C}$ not to use the dock but also a duty to use it, owed to his passengers or (if this is not $\mathrm{D}$ himself) the shipowner. It is true, of course, that one can find that different cases or statutory provisions lay down conflicting or ostensibly conflicting legal rules. But where the law is settled, one would think that it must have taken a position on which duty should prevail and so what, according to the law, D ought to do, all things considered. This must surely be the case where a party is compelled to perform his legal duty, but even where this is not the case and the only remedy available is compensation, the law must surely resolve the dispute by prescribing a rule that can in principle provide guidance on how to act. At least as a general rule, one would think that conflicting rules would not coexist in settled law. In particular, it is difficult to see how a certain decision can be satisfactorily explained on the basis that it contains an unresolved conflict, as Gardner's approach implies. In fact, it seems clear that, if it had been able to act in time, the court in Vincent would

2. John Gardner, Wrongs and Faults, in APPRAising StRict Liability (A.P. Simester ed., 2005).

3. Id. at $8, \mathrm{n}$. 13. The problem of two parties each entitled to use reasonable force against the other really arises when one or both of them does not have actual or constructive knowledge of the true facts. 
have ordered $\mathrm{C}$ not to prevent $\mathrm{D}$ from mooring at the dock and would not have ordered D not to moor at the dock, because D's act was not, all things considered, wrongful. ${ }^{4}$

Kramer also takes the view that $\mathrm{D}$ was committing a wrong against $\mathrm{C}$, but he says that nevertheless $\mathrm{C}$ was not at liberty to stop him doing so. ${ }^{5}$ In other words, the effect of the emergency was not that $\mathrm{D}$ was in law free to use the dock but that $\mathrm{C}$ was not free to stop $\mathrm{D}$ from using the dock, even though $\mathrm{D}$ still had a duty not to use it and was acting in breach of this duty. By contrast, in the absence of an emergency, C could presumably have used reasonable force to prevent $\mathrm{D}$ from using the dock. It is indeed possible for $\mathrm{X}$ to have a duty not to use force to stop Y committing a breach of duty to X, though, in most circumstances, reasonable force to enforce one's rights is permitted. This is just to say that sometimes $\mathrm{X}$ is required to go to law to enforce his rights rather than use self-help in respect of a wrong against him by Y. But this analysis cannot explain Vincent either. Although it overcomes the problem in Gardner's analysis that each party is justified in using reasonable force against the other, there is still the problem of an unresolved conflict, namely that $\mathrm{D}$ has a duty not to use the property and also a liberty to use it, and the case cannot be explained on this basis. ${ }^{6}$ In any case it is unclear why the effect of the emergency should be to preclude $\mathrm{C}$ from using force to stop D breaching a duty to him rather than simply to suspend D's duty. In fact, it was surely the case that $\mathrm{D}$ did not in the circumstances commit a wrong by using the dock. ${ }^{7}$

4. This is particularly clear in the light of the earlier U.S. case of Ploof v. Putnam 81 Vt. 471, 71 Atl. 188 (1908), where a dock owner was held to have acted wrongfully in preventing a boat from mooring in an emergency; see Nigel Simmonds, Epstein's Theory of Strict Tort Liability, 51 CAMBRIDGE L.J. 113 (1992).

5. Matthew H. Kramer, Rights without Trimmings, in A Debate over Rights (Matthew H. KRAMER ET AL., 1998), at 15-17, esp. n. 6.

6. Kramer holds that contradictory or logically inconsistent relations cannot coexist but conflicting relations can; $i d$. at 19-20. But arguably, on Kramer's understanding of Vincent, D has vis-à-vis $\mathrm{C}$ both a duty not to use the dock and also a liberty to use it, which are contradictory rather than conflicting relations. Kramer refers to a hypothetical case in which two parties both have a right of exclusive possession of a plot of land. If this means simply that each has a duty to the other not to use the land, then they can certainly coexist. If both rights are respected, neither party will use the land. However, according to Kramer, the two rights can "eventuate" in one of the parties taking possession and paying the other compensation for breach of duty. But who is entitled to possession and who to compensation? The problem of conflict here cannot be avoided on the basis that one right is fulfilled or respected by the payment of compensation, any more than it can in the case of contradictory rights as in Vincent.

7. Waldron uses the distinction between whether $\mathrm{X}$ acts wrongly and whether $\mathrm{Y}$ is at liberty to interfere to stop X acting wrongly to explain that "a right to do wrong" is not paradoxical; Jeremy Waldron, A Right to Do Wrong, 92 ETHICs 21 (1981). The argument is explicitly concerned with moral rights and not legal rights. He discusses cases such as refusing to give to charity, supporting a racist political party, or being rude, where it appears that by virtue of a principle of personal autonomy there is a liberty to act wrongfully. But this does not appear to apply to Vincent, where in the normal case there would be no objection at all to preventing $\mathrm{D}$ from using the dock, which suggests that in the special circumstances of the case it was not wrongful to use the dock, not that $\mathrm{D}$ should not be prevented from acting wrongfully. Waldron himself 


\section{VIOLATION AND INFRINGEMENT AND ABSOLUTE OR CONCLUSIVE RIGHTS}

One way of trying to resolve the conflict, or apparent conflict, is by way of the distinction between violating and infringing a right. ${ }^{8} \mathrm{D}$ violates $\mathrm{C}$ 's right when, in breaching the duty owed to $\mathrm{C}$, he acts unjustifiably, all things considered. He merely infringes the right when, although he breaches his duty to $\mathrm{C}$, he acts justifiably overall. An infringement of a right justifies compensation, just as a violation does. Thus it is said that in Vincent, because $\mathrm{D}$ acted justifiably in the circumstances, he did not violate C's right but he did infringe it, and this is why compensation is justified. ${ }^{9}$ The conflict is resolved, or so it appears, because, although D committed a wrong for which he has to pay compensation, the overall position is that he was at liberty to use the dock.

A right is commonly understood as what might be called a protected interest. On this understanding, a right is an interest of C's that the law recognizes is worthy of protection, but the right is not absolute in the sense that it stipulates conclusively those acts of $\mathrm{D}$ that are, by virtue of the right, impermissible; there can be countervailing considerations that render it permissible for $\mathrm{D}$ to act contrary to the right. ${ }^{10}$

It might seem on this approach that any harm to the protected interest counts as infringement of the right and gives rise to a claim for compensation. But this surely cannot be a necessary implication of recognizing a right. ${ }^{11}$ There must be a distinction between a mere harm to C's interest and an infringement. An infringement is a breach of duty, and a harm to the interest is not necessarily a breach of duty. Harm to C's interest is not the only consideration in determining whether there is a duty; in some circumstances, countervailing considerations mean that $\mathrm{D}$ does not have a duty

says that in private law, a liberty to act on the part of one party must correspond to the absence of a right on the part of the other; $i d$. at 24.

8. Judith Jarvis Thomson, The Realm of Rights (1990), at 122; and Thomson, Self-Defense and Rights, in Rights, RESTITUTION AND RISK (William Parent ed., 1986), at 40.

9. Thomson, $i d$. at 101; and Thomson, Rights and Compensation, in Rights, Restitution AND Risk (William Parent ed., 1986); J. Feinberg, Voluntary Euthanasia and the Inalienable Right to Life, 7 PHIL. \& PUB. AfF. 93 (1978), discussing a hypothetical case analogous to Vincent; Jules L Coleman, Risks and Wrongs (1992), at 371-372.

10. This concept of a right has been propounded by, e.g., Joseph Raz, The Morality of FreEdom (1988), at 166; and D.N. MacCormick, Rights in Legislation, in LAW, MoRALITY AND SOCIETY (P.M.S. Hacker \& J. Raz ed., 1977), though not by Thomson. The concept reflects a consequentialist or welfare-based approach to rights.

11. This would amount to liability for loss based purely on a test of causation of a certain type of harm, which raises a problem of indeterminacy. Taking causation to be purely a factual and value-free matter, where $\mathrm{X}$ suffers a loss from an act of $\mathrm{Y}$, one can always say that the loss was caused by $\mathrm{X}$ for failing to avoid the harm, as well as by Y; it seems that a distinction between the two, even if expressed in terms of causation, can be made only by reference to a duty of some sort imposed on Y. See Stephen R. Perry, The Impossibility of General Strict Liability, 1 CAN. J. L. \& JuRisprudence 147 (1988), discussing Richard Epstein, A Theory of Strict Liability, 2 J. Legal Stud. 151 (1973); and relying on Ronald Coase, The Problem of Social Cost, 3 J. L. \& ECON. 1 (1960). But see infra note 31. 
and does not commit a breach of duty by harming C's interest. But, if so, one might ask, should one not take all such countervailing considerations into account, so that if $\mathrm{D}$ acts justifiably in the circumstances, all things considered, he does not commit a breach of duty at all? This appears to be the position of one of the leading proponents of the protected-interest concept of the right. According to Raz, if, in particular circumstances, there are countervailing considerations that outweigh the considerations in favor of protecting the C's interest, though $\mathrm{C}$ may still be said to have a right, D has no duty, and this is surely intended to imply that no claim for compensation for harm to the interest can arise in those circumstances. ${ }^{12}$ The reason for this must be that the availability of a claim for $\mathrm{C}$ against D on the ground of D's wrong should depend not just on whether C has a right in the protected-interest sense, but on whether $\mathrm{D}$ acted wrongfully or unjustifiably, all things considered. If $\mathrm{D}$ acted exactly as he should have done in the circumstances, all things considered, it is unjust that he should incur a liability for compensation on the ground of wrongdoing, as the violation/infringement distinction allows.

This is consistent with the position with respect to broadly expressed fundamental rights or human rights such as a right to personal security or a right to privacy. The scope of such rights is often in issue, but it does not appear generally to be thought that the question whether $\mathrm{D}$ has acted wrongfully or unjustifiably, all things considered, is distinct from the question whether $\mathrm{D}$ should be required to pay compensation to $\mathrm{C}$.

The point can be clarified by contrasting the protected-interest concept of the right with the concept of the fully specified, absolute or conclusive right. A fully specified right, although based on an interest, is in its definitive formulation qualified or specified so as to accommodate countervailing rights or other considerations and so avoid a conflict. ${ }^{13}$ The full specification provides for all possible contingencies, so that the right is absolute or conclusive in the sense that it can never be justifiably overridden (but there is no implication of a very powerful or far-reaching right). In particular circumstances, either D has a duty, all things considered, or C has no right that can be infringed, and $\mathrm{C}$ has a claim against $\mathrm{D}$ for compensation for a breach of duty only if $\mathrm{D}$ has acted wrongfully, all things considered.

There has been some controversy over these rival concepts. The fully specified conclusive right is criticized for lacking any weight in argument. ${ }^{14}$ In many contexts, a right is weighed against other considerations or invoked to override other considerations, and a conclusive right cannot play this role

12. RAZ, supra note 10 , at 183 .

13. As to the idea of fully specifying or conditioning rights, see Thomson, Self Defence, supra note 8, at 37; and Thomson, REALm OF Rights, supra note 8, at 89; John Oberdiek, Lost in Moral Space: On the Infringing/Violating Distinction and its Place in the Theory of Rights, 23 LAW \& PHIL. 325 (2004); Russ Shafer-Landau, Specifying Absolute Rights, 37 ARIZ. L. REV. (1995); John FINNIS, NATURAl LAw AND NATURAl Rights (1979), at 218; Kramer, supra note 5, at 42-48.

14. Thomson, Self Defence, supra note 8, at 38-39. 
because all such considerations have already been taken into account in the formulation of the right. But the conclusive right is apt for expressing the settled legal position once the arguments are over and all considerations have been taken into account. This is what is required for the standard legal usage in stating a claim or a decision. ${ }^{15}$ Thus both concepts are important. A right in the protected-interest sense provides a nonconclusive reason for a rule, and a right in the conclusive sense is a statement of the definitive rule, from the standpoint of the person whose interest the rule protects. ${ }^{16}$

Thus it appears that the concept of a right in the protected-interest sense can be reconciled with the concept of a conclusive right through the idea of the degree of abstractness or concreteness of a right. The most abstract right is a broadly stated and unqualified right, tantamount to an interest, and the most concrete right is a fully specified, conclusive right. In particular circumstances, there may be or appear to be a conflict between abstract rights, but their resolution as concrete rights in the light of the particular circumstances determines which prevails and avoids any conflict in a final statement of the law. ${ }^{17}$ Rights having some degree of abstractness have some degree of weight also and are to some degree unspecified. Alternatively, a right to a reasonable standard of conduct has the form of a conclusive right though it is not fully specified. Rights in the protected-interest sense, and all other considerations, are resolved in the assessment of what is reasonable. This seems to be what happens in the law of negligence. These approaches operate in effect with a conclusive right but without needing it to be fully specified. Thus they overcome, at least for practical purposes, another objection made to conclusive rights: that in practice a fully specified right can never actually be formulated, because it is impossible to anticipate all possible contingencies and countervailing considerations and still less to work out their significance in advance. ${ }^{18}$

On the approach above, where $\mathrm{C}$ has a claim for compensation arising from a wrong by D, D's wrong is the breach of a conclusive duty, which means that there is no room to say that $\mathrm{D}$ was justified in committing the wrong; and conversely, if $\mathrm{D}$ acted justifiably, there is no possibility of a claim for compensation based on a wrong by $\mathrm{D}$. There is, in other words, no room for the infringement/violation explanation of Vincent.

However, some writers would certainly insist that the nature of rights is such that they cannot always be reconciled and a conflict between them avoided by specifying them or making them concrete in particular

15. See Nigel Simmonds, Central Issues in Jurisprudence (2d ed. 2002), at 283, referring also to FINNIS, supra note 13, at 210.

16. As to a distinction between two concepts along these lines, see, e.g., Simmonds, supra note 15, at 285-286; John Bell, Policy Arguments in Judicial Decisions (1983), at 207; FinNis, supra note 13 , at 218. The distinction is not the same as that between the interest theory and the will theory, but see SimMONDS, supra note 15, at 200.

17. See Ronald Dworkin, Taking Rights Seriously 294-331 (rev. ed. 1977). Cf. Kramer, supra note 5 , at $42-48$.

18. Thomson Self Defence, supra note 8, at 39. 
circumstances in this way, ${ }^{19}$ and therefore that there can be cases where D acts justifiably but nevertheless commits a breach of his duty to C. This is the type of case where it seems to make sense to invoke a distinction between violation and infringement. The difficulty, as pointed out above, is that if there is good reason to say that $\mathrm{D}$ acts justifiably in the circumstances, there seems also to be good reason to say that C's right, and D's correlative duty, are in the circumstances qualified, so D does not act wrongfully. But maybe this is too simple, and there are indeed cases where it is right to say that $\mathrm{D}$ acted justifiably overall but also wrongfully toward C. In any case, in my view there is another way to understand at least some of the cases that might be interpreted in this way, including Vincent. If C suffers loss as a result of D's doing $\mathrm{X}$, and the court holds that $\mathrm{D}$ was justified in doing $\mathrm{X}$ (so that, if the issue arose, he would not be ordered not to do $\mathrm{X}$ or punished for doing it) but nevertheless requires $\mathrm{D}$ to pay compensation to $\mathrm{C}$, it should not be assumed that the ground for D's liability for compensation is that he acted wrongfully by doing $\mathrm{X}$. In my view, the problem with all the suggested explanations of Vincent above is, indeed, that they assume that it is necessary to base C's claim for compensation on a wrong by D. The solution lies in recognizing that $\mathrm{D}$ was liable to pay compensation despite the fact that he did not behave wrongfully toward $\mathrm{C}$ and in explaining why this is.

\section{THE CLAIM ARISING FROM UNAUTHORIZED USE}

Say D uses C's property without permission. Let us say that the unauthorized use causes $\mathrm{C}$ no loss: there is no damage to the property, and $\mathrm{C}$ would not himself have used it or hired it out. Nevertheless, it is well established in English law (and I will assume that it is justified) that D is liable to pay a reasonable sum as a sort of deemed license fee, assessed as what might reasonably have been agreed. ${ }^{20}$ This ostensibly simple claim has given rise to considerable controversy. ${ }^{21}$

The claim is understood to arise from D's breach of his primary duty not to use A's property. But a remedy for a wrong should be designed to correct the wrong or its effects. Where D has wronged $\mathrm{C}$, it is understandable that $\mathrm{D}$ might be ordered to fulfill the duty or provide some equivalent performance, or to compensate $\mathrm{C}$ for harm caused by the breach of duty; these are remedies for the wrong. But the claim for a reasonable payment cannot be explained in this way, and it is difficult to see how the claim is related to this primary duty.

19. This might be but is not necessarily associated with opposition to the protected-interest theory of rights.

20. See, e.g., Strand Electric \& Engineering v. Brisford Entertainments (1952) 2 QB 246.

21. This is apparent from the standard texts on restitution and unjust enrichment. 
One possibility is the so-called "opportunity to bargain" argument. ${ }^{22} \mathrm{Be}-$ fore the unauthorized use, $\mathrm{C}$ could have insisted that $\mathrm{D}$ pay him a license fee. By using the property without taking a license, $\mathrm{D}$ has deprived $\mathrm{C}$ of the possibility of bargaining for a license fee, and the loss is the license fee $\mathrm{C}$ would have insisted on. But this makes sense only if the primary relation is not a duty not to use the property but instead a duty to take a license and use the property. Clearly there is no such duty, because $\mathrm{D}$ is entirely free not to use the property at all and not to take a license. ${ }^{23}$

Another argument is that the claim is based on the principle that a wrongdoer should not profit from his wrongdoing. D acts wrongfully by using C's property without permission and is forced to pay the deemed license fee in order to remove the profits of wrongdoing. ${ }^{24}$ But a claim based on this principle should be a claim for all the profit of the wrong, whereas, under a claim for a deemed license fee, D merely pays some proportion of his benefit, being the proportion that it is considered might reasonably have been agreed as a license fee. This makes no sense as the response to the "wrongdoer's profits" principle. ${ }^{25}$

Another explanation has been proposed by Weinrib. ${ }^{26} \mathrm{He}$ argues that, in this type of case, $\mathrm{C}$ has a right against $\mathrm{D}$ that includes a right to the "opportunity to gain." ${ }^{27}$ In such a case, he argues, D's duty is not merely a duty not to harm $\mathrm{C}$ but a duty not to benefit through the use of C's property. Discussing a case involving the unauthorized use of a machine, he says:

The defendant was under a duty to the plaintiff not to use the plaintiff's machine. By owning the machine, the plaintiff also owned the value that

22. R.S. Sharpe \& S.M. Waddams, Damages for Lost Opportunity to Bargain, 2 OXFORD J. LEGAL STUD. 290 (1982). Cf. the argument that D's failure to secure consent from C can be a wrong (where use is justified): ColEman, supra note 9, at 299-302.

23. One might argue instead that $\mathrm{D}$ has a duty not to use the property without taking a license. This might seem to imply that if $\mathrm{D}$ uses the property without a license, he must then, as it were, complete the performance of his duty by taking a license and paying for it. But if D has already used the property, then, with respect to this past use, it is no longer possible to get a license. If $\mathrm{D}$ comes to a settlement with $\mathrm{C}$ over C's claim against him, this might be referred to as a retrospective license, especially if it is part of a genuine license for continuing use. But the settlement is over a claim that has already accrued for the payment of a license fee. In fact, it is doubtful whether the duty not-to use the property without taking a license is different from the ordinary duty not to use the property. Alternatively, one might say that there is a duty to pay for a license if one uses the property. But on this formulation, the duty to take a license does not, in any case, arise from a duty not to use the property at all; see further text at n. 38 infra.

24. This argument was used by Denning L.J. in Strand Electric \& Engineering v. Brisford Entertainments (1952) 2 QB 246, 254.

25. The cases in which an award of this kind is made also do not generally rely on this principle, which is forcefully invoked in other types of cases.

26. E.J. Weinrib, Restitutionary Damages as Corrective Justice, 1 THEORETICAL INQUIRIES IN LAW 1 (2000). Weinrib and others describe the claim as a restitution or unjust enrichment claim, but there is nothing in the idea of restitution or unjust enrichment that overcomes the problem stated in the text. Cf. E.J. WEINRIB, ThE IdEA OF Private LaW 196 (1985).

27. Weinrib, Restitutionary Damages, supra note 26, at 8-12. 
could be realised from using it. Since that value is an incident of the plaintiff's proprietary right, it is also an element in the duty correlative to that right. ${ }^{28}$

In other words, the remedy for the breach of duty must reflect the content of the duty. Since D's duty encompasses a duty not to exploit the possibility of gain, the remedy must encompass the benefit acquired through the breach of duty, since this benefit represents the realization of the opportunity to which $\mathrm{C}$ was entitled.

This argument seems to me flawed as well, for the reason mentioned above- that the remedy should serve to correct the breach of duty. If, in breaching the duty, D prevents $\mathrm{C}$ from realizing an opportunity for profit or diverts to himself an opportunity for profit, D's benefit will also be C's loss and is recoverable as such. ${ }^{29}$ But if the breach of the duty does not affect $\mathrm{C}$, as in the case of a use that does not deprive $\mathrm{C}$ of personal use or of the prospect of profit through licensing, then the loss caused is nil, and this is the case even if the duty is a duty not to profit and D has profited by the breach. $^{30}$

In my view, the answer is that the claim for a deemed license fee does not arise from D's breach of a duty not to use the property, or from a breach of duty at all. The basis of the claim is as follows. C, as the owner of property, has, by virtue of his ownership, the right to all its value, including its use-value, meaning the value to be made through the use of the property. If $\mathrm{D}$ uses C's property, the benefit $\mathrm{D}$ receives comes from a combination of the use-value of the property and his own action in using it. C's right to the use-value of the property entails a right to the proportion of D's benefit attributable to the use-value of the property. This can be measured as a reasonable "license fee" for the use of the property. D may have a duty not to use the property, but C's claim does not arise from a breach of such a duty. It is not the fact that D's use was wrongful that generates the claim; it is the unauthorized use itself, given that $\mathrm{C}$ is entitled to the use-value of the property.

The claim for a deemed license fee arises not from a breach of duty but from a liability. "Liability" is used in the sense that someone subject to a liability is susceptible to a change in his legal position, here the change being the accrual of a claim against him. The unauthorized use is a "causative event" that generates a claim, though it is not in itself a breach of duty. C's primary right, the right by virtue of which his claim arises, which is in this case his right of ownership or an aspect of it, is correlated not with a duty

28. Id. at 24 .

29. This will often be the case for a breach of fiduciary duty.

30. D can have a duty not to do X, or not to do X for the purpose of making a profit, or not to do $\mathrm{X}$ in a way that will generate a profit, but to say that $\mathrm{D}$ has a duty not to make a profit from doing $\mathrm{X}$ is really just a way of disguising the fact that removing the profit is a legal response to the breach of duty not to do X. Weinrib makes clear that he does not mean to rely on the wrongdoer's profits principle mentioned supra; Weinrib, Restitutionary Damages, supra note 26 , at 6 . 
but with a liability. I will say that there is a "right-liability" or "primary liability" relation. A primary liability or right-liability relation is, in general terms, an allocation of risk between $\mathrm{C}$ and $\mathrm{D}$. $\mathrm{C}$ acquires a claim against $\mathrm{D}$ if a certain contingency materializes, but $\mathrm{D}$ does not have a duty to prevent it from materializing, and the claim does not arise from a wrong. (I will come back to the nature of the right-liability relation.)

Conventionally it would be said that a right of ownership of property is correlated with the duty of others not to use the property. On the above analysis, it is a right-liability relation that defines the scope of C's right of ownership. One can see how such a relation is apt to reflect the nature and rationale of property ownership. Its function is (broadly speaking) to allocate resources among people and, accordingly, to define the scope of each owner's property right vis-à-vis others and to secure to him the value and benefit of his property. Thus it confers a "right to a thing," not (or not only, or most directly) in the sense that others have a duty not to interfere with the owner's use of the thing or use it without permission, but in the sense that the owner can claim payment for its unauthorized use whether or not there has been a breach of duty.

This is not to say that there is no duty not to use the property; the point is that the duty not to use the property is not correlated with the right of ownership nor definitive of the scope of the right of ownership. ${ }^{31}$ The duty not to use the property is not a duty in property law but a duty in tort, which determines not the scope of C's property right but the extent to which D should be constrained in his freedom to act in order to protect the interests of C. C's interests include his interests in his person and privacy and also in his property, and for the purposes of the duty in tort, C's interest in his property must depend on a prior definition of the scope of the property right, and this is supplied by the right-liability relation.

For example, consider a variation of Vincent. Say that (by contrast with the actual facts of the case) D is cruising in the lake and is caught in a storm and pushed against C's dock by the wind. Here the issue is whether D has breached his duty of reasonable care in his control of his boat. There is no question of any liability to pay compensation unless D has committed a wrong in this way. Such a claim is in tort, but it must presuppose a definition of the scope of the property right, which cannot be the correlate of the tortious duty of care. In the case where, as in Vincent itself, D actually uses C's property, the unauthorized use will generally be a breach of duty not because unauthorized use is per se a breach of duty but because C's interest in his property, as defined by the right-liability relation, will, except in special circumstances, generate a duty in tort not to use it. Thus the distinction between the right-liability relation that defines the scope of the

31. Perry objects to the "metaphor of the boundary" because, as mentioned supra note 11, if a claim for compensation arises from a breach of duty, it cannot also arise from any harm to a defined interest. But the objection does not apply to primary-liability claims. See Stephen R Perry, Libertarianism, Entitlement, and Responsibility, 26 PHIL. \& PUB. AfF. 351, 389 (1997). 
property right and the duty in tort not to use it is not ordinarily visible. But unauthorized use of the property will not invariably be a breach of duty. In an emergency, as in Vincent, D has an exceptional interest in using C's property, and this may have the effect that $\mathrm{D}$ is free of the duty he would otherwise have not to use it. However, this will not affect the scope of C's property right as defined by the right-liability relation. In the circumstances, D may be free to use the dock, but it does not cease to be C's property. Even if the unauthorized use is not wrongful, by virtue of the primary-liability relation there can still be a liability to make a reasonable payment for the unauthorized use. This explanation of Vincent avoids the need to rely on the idea of a justified wrong or an irresolvable conflict of rights or a breach of duty that constitutes an infringement of a right but not a violation of it. The right-duty and right-liability relations are conclusive in the sense discussed above, but they are not in conflict with each other.

One might object that the measure of recovery in Vincent-compensation for loss-is inappropriate for the claim as explained above. But the measure seems to me defensible. Often, where there is an unauthorized-use claim, there has been no damage to C's property or other loss to C. The unauthorized-use claim does not depend on C's having suffered any loss. The measure of recovery should normally be some proportion of the benefit received by $\mathrm{D}$ from the unauthorized use. But where there is loss through the unauthorized use, the deemed license fee should generally cover it. The benefit to $\mathrm{D}$ here was avoiding damage to the boat. One would think that this would certainly have exceeded the cost of damage to the dock, and maybe in an emergency it is reasonable to limit $\mathrm{C}$ to the recovery of his loss. Thus, strictly speaking, the claim in Vincent was not for compensation for loss resulting from a breach of duty but for a deemed license fee assessed to cover C's loss.

One could also conceive of a type of property for which it might be unnecessary for the law to impose any duty at all not to use the property, so that D is always free to use C's property but, by virtue of the rightliability relation, incurs a liability to pay a reasonable amount for the use of the property if he does use it. One could imagine an intellectual-property system for which this is the case. This would directly reflect the rationale of the system in securing to the owner a reasonable return on the intellectual property without limiting the general availability of the intellectual property. No doubt it would be quite impracticable, ${ }^{32}$ but the possibility at least illustrates the distinction between the two types of legal relation. In the case of ordinary tangible property, such an arrangement would certainly be unworkable, because it is crucial to be able to exclude people from the property in order for it to be usable by anyone.

32. There would certainly be difficulties of monitoring and enforcement. Also, at least in some circumstances, one might argue that an intellectual property right is not designed purely to secure a financial return but to give control over the use of the intellectual property. However, it is worth noting that intellectual property law recognizes "compulsory licensing." 


\section{INVALID TRANSFERS}

A similar analysis applies to what is actually the much more common case of an invalid transfer of property. By "invalid transfer" I mean a transfer of property (including money) that is not made by way of the valid exercise by the owner of his power of transfer-for example, a putative transfer made by mistake or under duress, or by an agent or trustee without authority, or where there is not even the possible appearance of authority for the transfer, as where the property is lost and found or simply taken without permission.

Where there is an invalid transfer of C's property to D, C generally has and in principle should have a claim to recover the property or its value from the time of its receipt by $\mathrm{D}$. There is no reason to think that this claim is based on a wrong by $\mathrm{D}$. The invalid transfer is generally beyond D's control, and he may be quite unaware that he has received it. Even accepting the possibility in some circumstances of a strict-liability duty or fault-free wrong, it is difficult to see why it should be necessary to characterize the transfer or receipt as a wrong in order to explain the claim. Like the unauthorizeduse claim considered above, the claim arises from C's right to his property, which gives $\mathrm{C}$ a claim against the recipient $\mathrm{D}$ without the need for $\mathrm{D}$ to have committed a breach of duty. It is a primary-liability claim, and, like the unauthorized-use claim, this primary-liability claim is explicable in terms of the nature of property ownership. The owner has a right to his property, not in the sense that others have a duty not to take it but in the more basic sense that he has a claim to recover it or its value from a recipient to whom it has been invalidly transferred, whether or not the recipient has committed a wrong. ${ }^{33}$

This is not to say that D may not sometimes act wrongfully with respect to C's property. He may act wrongfully by taking it without permission or, having received it through an invalid transfer, he may act wrongfully by consuming it or disposing of it. The point is that a claim based on the breach of such a duty is distinct from the claim to recover the property or its value. The former is a claim for compensation for loss caused by a wrong, whereas the latter is a claim to recover the property transferred or its value, and this is a primary-liability claim that arises from the receipt of an invalid transfer of property, which is not itself a wrong. Furthermore, one would expect that D's duty is not simply a duty not to dispose of or consume the property invalidly transferred but, more generally, a duty to take reasonable care with respect to receipts, and this suggests that $\mathrm{D}$ may be liable to pay compensation only if he knew or ought reasonably to have known of the invalid transfer. By contrast, there is no reason why D's knowledge or other considerations relating to the reasonableness of D's behavior should be

33. One might object that all $\mathrm{C}$ has or needs is a liberty to recover his own property. But in fact, C's claim will often be a claim to money in D's account, which has to be pursued by legal proceedings; see Peter Jaffey, Hohfeld's Power-Liability/Right-Duty Distinction in the Law of Restitution, 17 CAN. J. LAW \& JURISPRUdENCE 295 (2004). 
relevant to the scope of C's property right or, therefore, to the primaryliability claim.

An adequate regime in respect of invalid transfers should incorporate both types of claim. The traditional law of equity concerning the recovery of transfers in breach of trust or fiduciary duty can indeed be understood in this way, though this would not be an entirely conventional formulation. ${ }^{34}$ But often the law attempts to do without the distinction between the two types of claim, and then problems arise, just as they have in a case like Vincent concerning unauthorized use. Say the law tries to make do with a single wrong-based claim. If the wrong is taken to have been committed on receipt, then the law is committed to a strict-liability duty. This is liable to be unjust to a recipient who does not know and has no reason to know that the transfer was invalid. On the other hand, if the law takes the position that the wrong is committed only when the recipient knows or ought to know of the invalidity of the transfer, there is no way to explain the claim to recover the property that must arise on receipt. This problem has long been known by tort lawyers to create an awkward tension in the law of conversion.

As in connection with Vincent, the problem here can be seen as an apparent conflict of rights. If one tried to express the legal position in terms only of rights corresponding to duties and wrongs or breaches of duty, one would have to say that $\mathrm{C}$ has a right to recover his property corresponding to a duty of $\mathrm{D}$ not to receive it or to return it on receipt, and also that $\mathrm{D}$ has a liberty to destroy or dispose of property that he has good reason to think is his own, that is, before he knows or ought to know that the transfer was invalid and becomes subject to a duty not to destroy or dispose of the property. In a case where D consumed or disposed of property received from $\mathrm{C}$ in ignorance of the fact that it was invalidly transferred, one would then have to say that $\mathrm{D}$ committed a wrong against $\mathrm{C}$ but at the same time acted justifiably. The conflict is analogous to that in Vincent, but, as mentioned above, this type of case is actually much more common. As in Vincent, the ostensible conflict cannot be satisfactorily resolved if the law employs only a single wrong-based claim to deal with invalid transfers. It can be resolved only by distinguishing between the two types of claim and recognizing the primary-liability claim.

Thus, in connection with invalid transfers just as with unauthorized uses, one can distinguish between the primary-liability claim, here a claim to recover property, and the claim for compensation for breach of a duty, here a duty to take reasonable care not to destroy or dispose of someone else's property. The two types of claim have different rationales. The primaryliability relation defines the scope of C's property right vis-à-vis D and others and so serves (broadly speaking) to allocate resources among people and to secure to each property owner the value and benefit of his property by way of the primary-liability claim. The duty not to use the property or not 
to dispose of it or destroy it is a matter of tort law, the function of which is, broadly speaking, to determine the extent to which $\mathrm{D}$ should be constrained in his freedom to act in order to protect the interests of $\mathrm{C}^{35}$

\section{WHAT IS A PRIMARY-LIABILITY CLAIM?}

\section{Right-liability versus Right-duty Relations}

Usually claims arise from a wrong or breach of duty. It is sometimes assumed that this is the case for all claims. This is behind the difficulties discussed above. I have suggested that some claims arise that are not wrong-based or duty-based. They arise from a primary right of C's correlated with D's primary liability. $\mathrm{D}$ is subject to a liability in the sense that his position is subject to alteration by the accrual of the claim, without any breach of duty on his part. In general terms, a primary right-liability relation is a direct allocation of risk as between $\mathrm{C}$ and $\mathrm{D}$. It imposes on $\mathrm{D}$ a risk relating to a certain contingency, which may or may not involve an act by D. D bears the risk of the contingency in the sense that he is responsible for remedying its effects on $\mathrm{C}$, but he does not have a duty to prevent the contingency from materializing. In the cases discussed above, the claim is justified in order to protect C's right of ownership of property. There are other types of claim that are not based on a breach of duty but on a primary right-liability relation. This may be the position under the rule in Rylands v. Fletcher; ${ }^{36}$ and in my view it is the usual position for contractual claims, though I will not attempt to discuss either of these types of claim here. ${ }^{37}$

Against the argument for right-liability relations, one might argue that the right-liability relation is really some form of right-duty relation. As discussed further below, the expression "strict liability" is ambiguous as between a primary liability and a strict-liability duty. But the primary liability is not a strict-liability duty. The primary-liability claim is not based on a breach of duty at all; sometimes it does not arise from an act of D's at all, and, if it does, it is an act that $\mathrm{D}$ was at liberty to do. It is not that $\mathrm{D}$ acted wrongly though without fault. Neither is it helpful to say that the primary liability is really just a conditional duty. One might say that $\mathrm{D}$ incurs a duty to make restitution, or make a reasonable payment, or provide some other sort of remedy, corresponding to C's claim, on the fulfillment of a condition,

35. This is not, of course, intended to provide general definitions of property law or tort law, merely to identify features of the two in a particular context.

36. (1868) LR 3 HL 330.

37. In contract, it is normally said that a claim against $\mathrm{D}$ arises from D's breach of a duty to perform, though $\mathrm{D}$ is not, as a rule, compelled to perform the duty. But the arguments advanced against compelling $\mathrm{D}$ to perform generally imply not that $\mathrm{D}$ has a duty that he should not be compelled to perform but that $\mathrm{D}$ does not in the circumstances have a duty to perform, for example because it would be in the public interest on grounds of efficiency. This is explicable on the basis that a contract gives rise to a primary-liability relation, not a right-duty relation. 
namely, the unauthorized use or invalid transfer or other causative event. This may be true ${ }^{38}$ but in this sense, the conditional duty is a remedial duty, and one could describe any remedial duty in the same way, whatever the nature of the primary relation. ${ }^{39}$ Thus this is no help in characterizing the primary relation from which the claim arises. Alternatively, one might argue that, when the causative event occurs, D becomes subject to a duty to provide restitution or a reasonable payment or some other remedy, and then a claim arises when $\mathrm{D}$ commits a breach of this duty by failing to pay, so the claim is wrong-based. But this is also unsatisfactory. As considered above, C's claim arises on the occurrence of the event. It may be that D commits a wrong by failing to satisfy the original claim, but, if so, this wrong is not the basis of the original claim. ${ }^{40}$

It also seems implausible to argue that there is no legal relation at all before the causative event occurs in cases like the ones above, though this appears to be the understanding of some commentators. For example, it is sometimes said that the causative event of unauthorized use or invalid transfer gives rise to a primary right, which is directly enforced through legal action. But the whole point of designating a right or relation as primary (in the relevant sense) is to identify it as the right or relation out of which the claim arises by virtue of a causative event, by contrast with the remedial right or relation that arises from the causative event, which is the claim or right of action. There must surely be a right subsisting before the causative event, which I identify in the cases above as the right of ownership or an aspect of the right of ownership.

\section{Duty Skepticism}

Sometimes arguments for claims not based on duties or wrongs are based on a general skepticism about the existence of duties. On one interpretation of the economic or utilitarian approach to law, the law regulates its subjects by creating incentives and disincentives rather than by prescribing rules that generate rights, duties, liabilities, and so on. The subjects are conceived of as responding to incentives and disincentives rather than following rules. This interpretation takes an external standpoint as opposed to the rule-following

38. In fact, a claim or remedial right to compensation is better understood as a power correlated with a liability, not a right correlated with a duty, and, on this basis, the position before the claim arises is in any case not a conditional duty; see Jaffey, supra note 33.

39. By contrast, where a condition is expressed in a contract or trust or possibly where an abstract duty such as a duty of reasonable care of a landowner to his neighbors is given specific content by a event such as an outbreak of fire on his land, one might more aptly say that the primary relation is a conditional duty, as in the example discussed in J.W. HARRIS, LEGAL Philosophies (2d ed. 1997), at 88.

40. It is true that in the end the significance of a right-liability relation depends on the enforcement of a duty, but this is true for other relations as well. It does not mean that it is reducible to a right-duty relation. 
internal standpoint. ${ }^{41}$ Similarly, as the legal-realist approach is usually interpreted, the law should be understood in terms of the sanctions that someone will be subjected to for doing certain acts or certain kinds of act rather than the rules he is subject to. ${ }^{42}$ This approach echoes what might be thought of as the traditional practical common lawyer's approach, according to which the law is a matter of remedies and anything else is fiction, or, if the concept of duty is recognized, it is used in an instrumental sense as a means of signifying that the law will apply a sanction in respect of an act. ${ }^{43}$

In criticizing externalist approaches for their skepticism over duties, some commentators seem to have assumed that on an internalist approach a claim must arise from a breach of duty and that any suggestion that claims arise other than from a breach of duty must reflect externalist skepticism. ${ }^{44}$ But the approach suggested above is not an externalist approach and it is not skeptical about duties or legal relations or rules. The primary-liability relation is a normative relation, like the right-duty relation. It is simply a different type or modality of relation from the right-duty relation, just as the power-liability relation has a distinct modality. It is, alternatively, a reason for action, though not a mandatory reason requiring an action from $\mathrm{D}$. As mentioned above, the relation can be understood as an allocation of risk, ${ }^{45}$ and this is a reason for action, though not a mandatory reason. Sometimes this type of relation is appropriate rather than a right-duty relation; this is a matter of the justification for the rule in question.

A similar point arises in connection with the concept of corrective justice. Many commentators argue that private law is a matter of corrective justice, though there is room for argument about what exactly is meant by this. On one view, to say that private law is a matter of corrective justice is to say that it serves to do justice as between the parties; and this is taken to imply that it must consist of right-duty relations between individuals and therefore that claims in private law arise from wrongs or breaches of duty by $\mathrm{D}$, the remedy serving to correct the wrong by undoing or rectifying its effect on

41. A standard tool of law and economics analysis is the distinction between property rules and liability rules. This important distinction is generally understood in externalist terms, i.e., in terms of legal responses as incentives or disincentives regulating conduct. Little effort has gone into trying to understand the two terms from the internal standpoint in terms of legal relations; but see Jules L. Coleman \& Jody Kraus, Rethinking the Theory of Legal Rights, 95 YALE L.J. 1335 (1986). In my view, the distinction is best understood as corresponding to the proposed distinction between right-duty relations and right-liability relations, though this raises a number of issues that cannot be considered adequately here.

42. O.W. Holmes, The Path of the Law, 10 HaRv. L. REv. 457, 458-461 (1987).

43. I.e., the "sanction theory of duty"; see P.M.S. Hacker, Sanction Theories of Duty, in OXFORD ESSAYS IN JURISPRUDENCE (2d ser., A.W.B. Simpson ed., 1973).

44. See, e.g., John Gardner, Backwards and Forwards with Tort Law, in LaW AND Social JusTiCE (Joseph Keim-Campbell et al. ed., 2005); see also Nicholas J. McBride, Duties of Care-Do They Really Exist? 24 OxFORD J. LEGAL STUd. 417 (2004). Some of MacBride's arguments are directed against duty-skepticism, though his real target seems to be the rather different argument that claims based on fault are not duty-based, though the two points are conflated.

45. This is an allocation of the risk of benefit and burden as between $\mathrm{C}$ and $\mathrm{D}$, not the risk of a sanction for breaching a duty. 
C. Consequently corrective justice theorists also generally insist that there is no room in private law for claims not based on a wrong. But the principle that in private law the remedy arises to protect and give effect to a primary legal relation between $\mathrm{C}$ and $\mathrm{D}$ (to express the principle more broadly), so that it serves to do justice as between the parties, is quite consistent with the possibility that the primary relation is a primary-liability relation in the sense discussed.

\section{Strict-Liability Duties}

Strict liability is widely thought to be unjust because there is liability without fault. If "liability without fault" refers to primary-liability claims, then the objection is misplaced. Claims not based on wrongdoing are sometimes justified, as the claims discussed above show. The objection is really to wrong-based or duty-based claims that do not involve fault, or in other words, strict-liability duties. It is at least on the face of it difficult to accept that someone can have a duty to do something that is beyond him or, in other words, that he can be liable on the basis of his wrongdoing when he was not at fault. ${ }^{46}$ Unfortunately "liability without fault" and "strict liability" are ambiguous as between strict-liability duties and primary liabilities.

The discussion above does not show that there are not strict-liability duties, but it does suggest that the law can be satisfactorily explained without them. For example, one commonly cited example of a claim arising from a strict-liability duty is the claim in conversion of a property owner against a recipient of his property that is mentioned above. ${ }^{47}$ The argument above suggests that this interpretation is mistaken. The law governing invalid transfers is better understood in terms of two distinct types of claim, a primary-liability claim and a claim arising from an ordinary duty of reasonable care, and the supposed strict-liability duty is an awkward and unnecessary conflation of the two.

Gardner refers to a remark of Nagel's that strict liability "may have its legal uses but seems irrational as a moral position." 48 Gardner reasonably objects that if it is not defensible in morality for someone to be treated as having acted wrongfully when he is not at fault, it is equally indefensible in the law. In my view, the "legal uses" of strict liability should be understood to refer to primary liabilities rather than strict-liability duties. But Gardner

46. The particular case of conflicting duties was referred to supra.

47. See, e.g., Arthur Ripstein, Philosophy of Tort Law, in The Oxford Handbook of JurispruDENCE AND PHILOSOPHY OF LAW (Jules Coleman \& Scott Shapiro eds., 2002), at 660.

48. John Gardner, Obligations and Outcomes in the Law of Torts, in RELATING TO RESPONSIBILITY: ESSAYS FOR TONY HONORE ON His EIGHTIETH BIRTHDAY (John Gardner \& Peter Cane eds., 2001), at 121, quoting Thomas Nagel, Moral Luck, in Mortal Questions (1979), at 31. Nagel also proceeds to argue that strict-liability duties are justifiable. Much recent discussion of strict liability seems to have been prompted by Honoré's work; see, e.g., TONY HONORÉ, RESPONSIBILITY AND FAULT (1999). 
attempts to defend strict-liability duties in law by showing that they are defensible in morality. ${ }^{49} \mathrm{He}$ distinguishes between duties to try and duties to succeed. Duties to succeed, which require the duty-bearer to achieve a certain outcome irrespective of whether he is capable of achieving it or whether he would be at fault for failing to achieve it, are strict-liability duties. The argument that there should be no strict-liability duties amounts to saying that all duties should be duties to try, and Gardner rejects this. Approaching the issue first in terms of reasons for action (a duty being a type of reason for action), he argues that there cannot be a reason to try to do $\mathrm{X}$ unless there is first a reason to succeed in doing X. Consequently, there must be straightforward reasons to succeed, and they are primary in the sense that reasons to try are derived from them. Furthermore there can be a reason to succeed in doing $\mathrm{X}$ even though there is no reason to try to do $\mathrm{X}$ because it is impossible to succeed in it. He gives the example of $\mathrm{D}$ at the top of a cliff watching a man drowning. D has, according to Gardner, a reason to succeed in saving the drowning man but no reason to try, because it is impossible for him to do anything to save him. Since a duty is a type of reason for action, Gardner suggests that there are also duties to succeed "such that failing to do as they would have one do would be wrong and hence could properly be made tortious in law," ${ }^{50}$ and these would be strict-liability duties.

If a man is drowning, one might say simply that there is a reason (for anyone) to save him. But say a particular person $\mathrm{D}$ sees a man drowning in the swimming pool in front of him. D has reason to take particular steps to save the man that depend on the particular circumstances, including his own capabilities. One might say that $\mathrm{D}$ has a reason to try and save the man or to take reasonable steps to save him, and this might be a convenient way of stating the position concisely and in a form applicable to people in various positions. D's reason to try to save the man is derived from the reason to succeed in saving him, but it would be misleading to say that there is still a separately subsisting reason to succeed in saving him. It would be better to say that the reason to succeed in saving the man that $\mathrm{D}$ has in common with others is a provisional or abstract reason that in D's case is modified or subsumed into the particular conclusive or concrete reason $\mathrm{D}$ has to act in his particular circumstances. In the case where $\mathrm{D}$ is at the top of the cliff above the drowning man, the abstract reason to save the man arising from the fact that he is drowning does not, in D's particular circumstances, give rise to any concrete reason to act; but again, it would be misleading to say that $\mathrm{D}$ still has, in these circumstances, a distinct reason to succeed in saving the man. In any case, there is nothing to suggest that in general

49. Gardner, supra note 48; see also Gardner, supra note 2. For an example of the use of "strict liability" to refer to a claim not arising from a wrong, see Kenneth W Simons, Justification in Private Law, 81 CoRnell L. Rev. 698, 710-711 (1995-1996).

50. Gardner, supra note 48, at 140. 
there might be a duty to succeed in doing something as opposed to a duty to take particular steps that are, in the circumstances, apt to achieve it.

No doubt there are other arguments for strict-liability duties, but it seems to me that the purposes of private law are adequately served by distinguishing between two modalities of rule: rules that direct or guide conduct by imposing duties and so generate claims based on wrongdoing, and rules that allocate risk directly-without imposing duties-by way of primaryliability relations and so generate claims in the absence of wrongdoing. ${ }^{51}$ Strict-liability duties are liable to obscure the distinction and conflate the two modalities of rule. Indeed by blurring the concept of duty in this way, advocates of strict-liability duties are in danger of succumbing to a form of duty-skepticism themselves.

\section{RIGHT-LIABILITY RELATIONS AND HOHFELD}

The usage of "right" and "liability" as I have used them in "right-liability relation" is at odds with Hohfeldian usage, where a right in the strict sense (a claim-right) is correlated with a duty, and a liability with a power. It might be thought that this contradicts Hohfeld's correlativity thesis, but this is not so. As Kramer points out, ${ }^{52}$ one can always use these expressions in a non-Hohfeldian sense. Kramer goes further and says that Hohfeld's correlativity thesis cannot be refuted because it is stipulated as a matter of definition by Hohfeld. ${ }^{53}$ It would be better to say that Hohfeld assumes a certain concept of legal rights and duties (and other such basic elements). Hohfeld's interest was in formulating legal rules unambiguously in terms of the legal relations between the parties and exposing hidden inconsistencies between different formulations. He was not concerned with the arguments involved in formulating legal rules from rights in the protected-interest sense. In other words, Hohfeld's system is based on the concept of the absolute or conclusive right (or duty, liability, etc.) as the means of stating a legal rule from the standpoint of a party regulated by it. The correlativity thesis follows because the rule regulates the position as between two people or classes of people, and it can equally be stated from the other standpoint. They are different sides of the same coin. This is the case with respect to a primary-liability relation just as for a primary-duty relation, and there is no question of contradicting the correlativity thesis. ${ }^{54}$

51. Leaving aside rules establishing liberty-no-claim relations and power-liability relations.

52. KRAMER, supra note 5, at 102-103. Harris suggests that where a bolt of lightning sets a tree alight and thereby imposes a duty of care on D, D was subject to a liability before the strike that was not correlated with a power. Thus he concludes that "not all liabilities are correlated with powers," and takes this to contradict Hohfeld's correlativity thesis; HARRIS, supra note 39. Harris's case is not a primary-liability case in the sense supra.

53. KRAMER, supra note 5, at 26-49, esp. 35.

54. A right in the protected-interest sense is taken not to be correlated with a duty, but see the discussion in $i d$. at $44-48$. 
But Kramer goes too far when he concludes his discussion of correlativity by saying that Hohfeld's scheme can "be employed to classify and clarify all empirical phenomena that might be found." ${ }^{55}$ Although Hohfeld no doubt intended his scheme to be complete in this sense, one cannot infer that it is actually complete from the concept of a legal right or legal relation that he adopted. If the argument above is right, and there are such things as right-liability relations, Hohfeld's scheme is indeed incomplete because it does not contain any such relation.

\section{CONCLUSION}

Private law is generally formulated in terms of right-duty relations, and accordingly private-law claims are understood to arise from breaches of duty, or wrongs. But some claims cannot be explained on this basis, because the claim arises from an act that $\mathrm{D}$ is justified in doing. A possible explanation for these cases lies in the violation/infringement distinction, but the apparent resolution of the inconsistency that the distinction offers seems to me illusory. In my view, in these cases C's primary right does not correspond to a duty on the part of $\mathrm{D}$, but a liability. Among the claims that arise from such primary-liability relations are claims for payment for the unauthorized use of property and claims to recover invalid transfers. Recognizing primaryliability claims does not involve duty-skepticism of the sort sometimes found in or attributed to the law and economics literature. Primary-liability claims arise by virtue of a legal relation between the parties, though the legal relation is not found in Hohfeld. A primary-liability claim is not a strict-liability claim in the usual sense in which the claim is understood to arise from the breach of a strict-liability duty. It may be that strict-liability duties are sometimes justified, but they are also sometimes mistakenly invoked to explain a body of law that would be better understood in terms of a combination of primary-liability claims and ordinary duty-based claims involving fault. 